\title{
EVALUATION OF SERUM EOSINIPHIL CATIONIC PROTEIN IN ASTHMATIC CHILDREN WITH VARYING DEGREE OF SEVERITY
}

\author{
A. Ahmed \\ Paediatric, National Research Center, Cairo, Egypt
}

The objective of this study was to evaluate the role of serum eosinophil cationic protein in relation to diagnosis and assessment of disease severity in asthmatic children.

Patients and methods: This study included 50 patients suffering from bronchial asthma of those attending the pediatrics clinic of National Research Center (NRC). Patients were diagnosed as asthmatic up on the classification of asthma severity according to GINA Guidelines. Twenty four healthy age and sex matched children were included as a control group. The study was approved by the Ethics Committee of the NRC. The exclusion criteria were history of allergic rhinitis, conjunctivitis, atopic eczema, infectious exacerbation, and parasitic infestation. All children included in the study were subjected to complete history taking, thorough clinical examination, pulmonary function tests and measurement of serum eosinophil cationic protein.

Results: There was a significant increase of serum ECP levels in patients compared with controls. $(\mathrm{p}=0.001)$, and significant positive correlation between ECP levels and severity of asthma. $(r=0.91, p=0.001)$. There was a significant decrease in forced expiratory volume in one second $\left(\mathrm{FEV}_{1} \%\right)(\mathrm{p}=0.001)$, peak expiratory flow rate (PEFR \%) $(\mathrm{p}=0.001)$ and forced expiratory flow 25-75\% (FEF 25-75\%) $(\mathrm{p}=0.001)$ in patients compared with controls. There was a significant negative correlation between ECP compared to $\mathrm{FEV}_{1} \%$ and PEFR\% $(\mathrm{r}=-0.78, \mathrm{p}=0.001)$.

Conclusion: Serum eosinophil cationic protein is raised significantly in asthmatic children. It has a significant positive correlation with the severity of asthma. So measurement of serum ECP can be used as a marker for assessing disease severity of asthma. 